\title{
Inhibition Studies of Cellulolytic Activities Isolated from Planococcus Citri
}

\author{
Muhammad Fayyaz-ur-Rehman ${ }^{1}$, Muhammad Ilyas Tariq, ${ }^{1, *}$ Mehwish Aslam ${ }^{1}$, Ghulam Khadija ${ }^{1}$ \\ and Aima Iram ${ }^{2}$
} ${ }^{1}$ Department of Chemistry, University of Sargodha, Sargodha-40100, Pakistan, ${ }^{2}$ Department of Biological Sciences,
University of Sargodha, Sargodha-40100, Pakistan

\begin{abstract}
The study was performed to isolate the cellulolytic activities from a mealy bug Planococcus citri and to check their enzyme inhibition against leaf extract of Azdirachta indica and Buxus Sempervirens. Enzyme assay confirmed the presence of endoglucanase activity. Aqueous and non-aqueous fractions showed the maximum inhibition. Proteins containing fraction also reflected inhibition of activity that might lead to identification of some active peptides against cellulolytic activity.
\end{abstract}

Key Words: Planococcus citri, Mealy bug, Cellulase inhibition, Buxus sempervirens, Azdirachta indica, Endoglucanse.

\section{INTRODUCTION}

Cellulose, the most copious biomass on the earth is degraded into its constituent residues by the cellulolytic enzymes (cellulases) secreted by microorganisms [1]; catalyze the hydrolysis of cellulose, yielding cellobiose and glucose monomers [2] which contribute to renewable energy. Gene isolation and characterization encoding cellulases show that cellulose hydrolysis in some invertebrate animal taxa is carried out by their own indigenously produced cellulases and is frequent amongst many invertebrates like nematodes $[3,4]$, arthropods [5, 6] and mollusks [7]. In case of lower animals, cellulose synergistically is degraded by flagellates, bacteria, and yeasts [8-10] as well as their own synthesized cellulases. The physiological functions of cellulases are distinct and depend on the source. In bacteria, the enzymes are involved in breakdown of fungal cell walls in order to allow them to be used as a food source [11] as well as bioremediation [12]. In case of pests, they possess symbiotic protozoans in the hind intestine for digestion of cellulose [13] and use a synergistic collaborative relationship with indigenously produced enzymes for the hydrolysis of cellulose to glucose.

Many plants are known to contain the drug bases as alkaloids, saponins, tannins, cardiac glycosides, and polyphenols and more than $30 \%$ of commercial drugs are being extracted by these plants [14]. In addition, plants can protect themselves against pests by synthesizing the specific macromolecules in the form of different enzyme inhibitors like protease inhibitors [15], amylase inhibitors [16, 17], lectins [18] and pectinase inhibitors [19] in addition to phenolic compounds. Cellulases are inhibited by the water soluble extract from forage Sericea [20] and grape extract. Tannins from the Robinia are shown to inhibit the $\beta$-glucosidase activity. The plants contain phenolic groups

\footnotetext{
*Address correspondence to this author at the Department of Chemistry, University of Sargodha, Sargodha-40100, Pakistan; Tel: +92-48-9230546; E-mail: tariqmi@uos.edu.pk,chemistry@uos.edu.pk
}

like $p$-coumaric and ferulic acids are reported to have inhibitory property of growth and cellulolysis against bacteria [21].

In Pakistan, Planococcus citri, a mealy bug causes extensive damage to citrus by sucking out sap and excreting honeydew causing distorted growth, premature leaf drop and disfigure plants by secreting cottony wax. Synthetic pesticides are being used for pest management through which mankind has greatly benefited but determent to peoples' health and environment [22]. Hence, the natural insecticides based on plant essential oils, in addition to a number of plant substances, have long been advertised as attractive alternatives to synthetic chemical insecticides for pest management. Apart from some natural mosquito repellents, little commercial success has ensued for plant substances for other purposes [23]. In the context of agricultural pest management, botanical insecticides are best suited for use in organic food production in industrialized countries but can play a much greater role in the production and post harvest protection of food in agro based countries like Pakistan. Keeping in view the facts, the study has been designed to screen some cost effective and environment friendly biological active extract from plants to control P. citri.

\section{MATERIALS AND METHODS}

Samples of $P$. citri were collected from the infested citrus plants in afternoon (Temp. $\approx 30-40^{\circ} \mathrm{C}$ ), for screening the presence of cellulase activity. Pests were haphazardly selected from infected leaves and stem and were stored at $4^{\circ} \mathrm{C}$ for further processing.

\section{Preparation of Crude Enzyme Sample}

Crude enzyme was prepared by taking a weighed quantity $(25 \mathrm{~g})$ of stored sample. Insects homogenized with $100 \mathrm{ml}$ $0.1 \mathrm{M}$ phosphate buffer $(\mathrm{pH} 7.0)$ and filtered. To filtered homogenate, ice-cold acetone $(400 \mathrm{ml})$ was added and kept overnight at $4^{\circ} \mathrm{C}$. The mixture was centrifuged at $10,000 \mathrm{rpm}$ for 15 minutes and was converted into pallets. These pellets were air dried and dissolved in $5 \mathrm{ml}$ of $0.1 \mathrm{M}$ phosphate and 
Tris- $\mathrm{Cl}$ buffer ( $\mathrm{pH} 6.0$ and 8.0). This was stored at $4^{\circ} \mathrm{C}$ and used as the enzyme source.

\section{Screening for Cellulolytic Activity/ Enzyme Assay}

A modification of Substrate-Agar Plate Assay [24] was used to screen the cellulase activity in crude protein extract by observing the cleared zone formation around the sample well, against a red-stained background on agar plates.

Agar gel was prepared by mixing 3\% agar and 1\% CMC at different ranges of buffer and was solidified by slow evaporation with a hole punched in the center of petri plates. A sample of $100 \mu \mathrm{l}$ crude protein extract was loaded in the hole and incubated at $50^{\circ} \mathrm{C}$ for 24 hours. The plates were then stained with $0.1 \%$ Congo red for $15 \mathrm{~min}$ at room temperature, followed by de-staining with sodium chloride solution (1 M) for 30min with gentle shaking.

After the confirmation of cellulolytic activity, enzyme assays was performed by measuring the amount of reducing sugar by using modified DNS (dinitrosalicylic acid) method $^{25}$, taking the glucose as standard. Concentration of the released glucose was measured from a standard glucose curve. Enzyme activity (U/ml) was determined considering one IU equal to $1 \mu \mathrm{mol} \mathrm{min} \mathrm{m}^{-1}$ of glucose formed during the hydrolysis reaction.

\section{Endoglucanase Activity (CMCase Assay)}

An aliquot $(100 \mu \mathrm{l})$ of the crude enzyme sample solution was added to $0.5 \mathrm{ml}$ of carboxymethyl cellulose (CMC) solution $(1 \% \mathrm{w} / \mathrm{v})$ in $0.1 \mathrm{M}$ sodium acetate buffer $(\mathrm{pH} 5.0)$. The mixture was incubated for $60 \mathrm{~min}$ at $50^{\circ} \mathrm{C}$ with gentle shaking. After incubation, enzyme activity was determined (Fig. 1) by using DNS method [25].

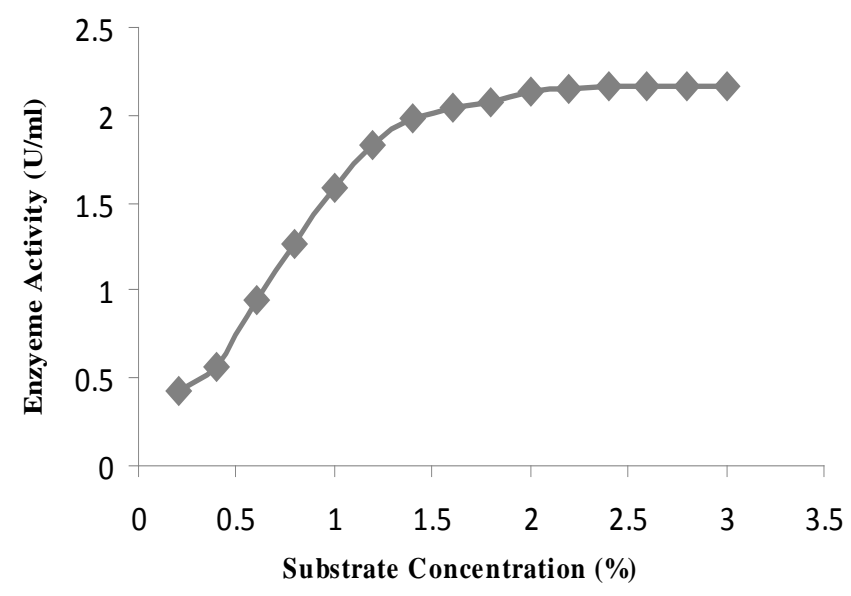

Fig. (1). Endoglucanase assay.

\section{pH and Temperature Optima of Enzyme Activities}

To determine the $\mathrm{pH}$ profile of cellulase activity, the enzyme assay was carried out using $0.1 \mathrm{M}$ buffers ranging from $\mathrm{pH}$ 4-8.9 using acetate buffer (4-5.4), phosphate buffer (5.8-6.8) and Tris-HCl buffer (7.1-8.9) which is presented in Fig. (2). The assay was performed in the same manner as in DNS method for the determination of $\mathrm{pH}$ profile for both endo- and exoglucanase activities. In order to determine the optimum assay temperature, the reducing sugars released from $\mathrm{CMC}$ were assayed at temperatures between $4-70^{\circ} \mathrm{C}$ by DNS method (Fig. 3).

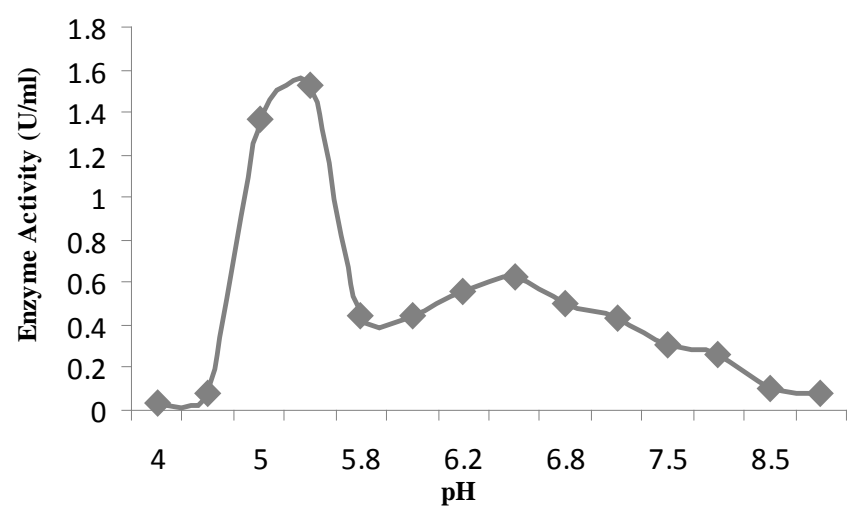

Fig. (2). $\mathrm{pH}$ optima for endoglucanase activity.

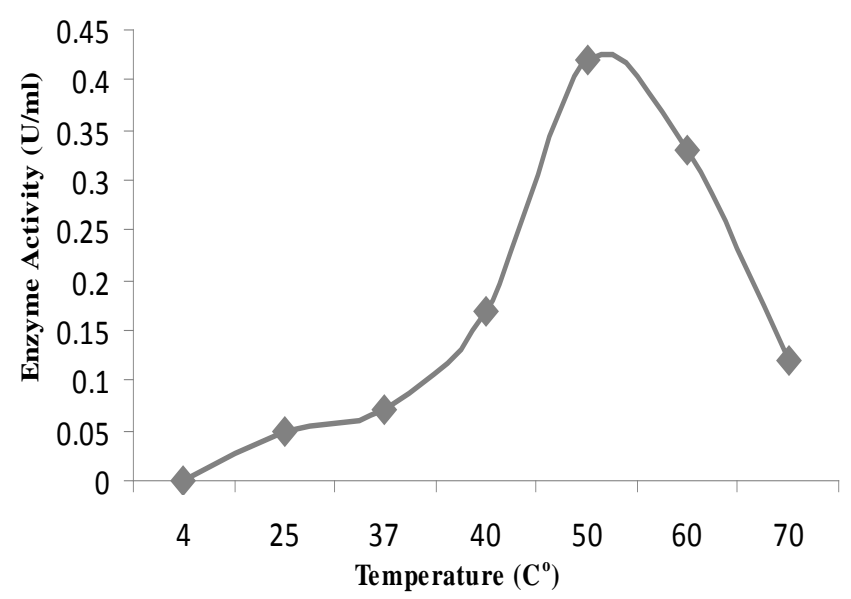

Fig. (3). Temperature optima for endoglucanase activity.

\section{Cellulolytic Enzymes Inhibition by Heavy Metals}

Endo and exoglucanase activities were studied in the presence of different concentrations of $\mathrm{Ag}^{+}, \mathrm{Pb}^{++}$and $\mathrm{Hg}^{++}$cations ranging from $10-100 \mathrm{ppm}$ in reaction mixture (Fig. 4). The reaction mixture contained $1 \% \mathrm{CMC}(0.5 \mathrm{ml})$, $0.1 \mathrm{M}$ acetate buffer $(0.5 \mathrm{ml}, \mathrm{pH} 5)$ and $100 \mu \mathrm{l}$ enzyme with variable concentrations (10-100 ppm) of lead acetate, silver nitrate and mercuric chloride.

\section{Cellulolytic Enzymes Inhibition by Plant Extracts}

\section{a. Azdirachta Indica and Buxus Sempervirens Leaf Extract Preparation}

Fresh leaves of Azdirachta indica and Buxus Sempervirens were collected, washed and dried to original weight. Extract from the leaf sample was obtained by homogenizing a weighed quantity of leaves $(50 \mathrm{~g})$ in $200 \mathrm{ml}$ of phosphate buffer $(\mathrm{pH} \mathrm{7.4)}$ and filtered. To $100 \mathrm{ml}$ of extract, cold acetone (400 ml) was added and kept it for overnight. Proteins were isolated in pellet form after centrifugation at $10,000 \mathrm{rpm}$. To determine the effect of these extracts upon enzyme activity, a reaction mixture was prepared containing $1 \% \mathrm{CMC}(0.5 \mathrm{ml}), 0.1 \mathrm{M}$ acetate buffer of $\mathrm{pH} 5.0(0.5 \mathrm{ml})$ and enzyme extract $(100 \mu \mathrm{l})$. To 
the reaction mixture, different fractions of $A$. indica and $B$. sempervirens leaf extract were added and incubated at $50^{\circ} \mathrm{C}$ for 24 hours. Their activities were determined and shown in Fig. (5).

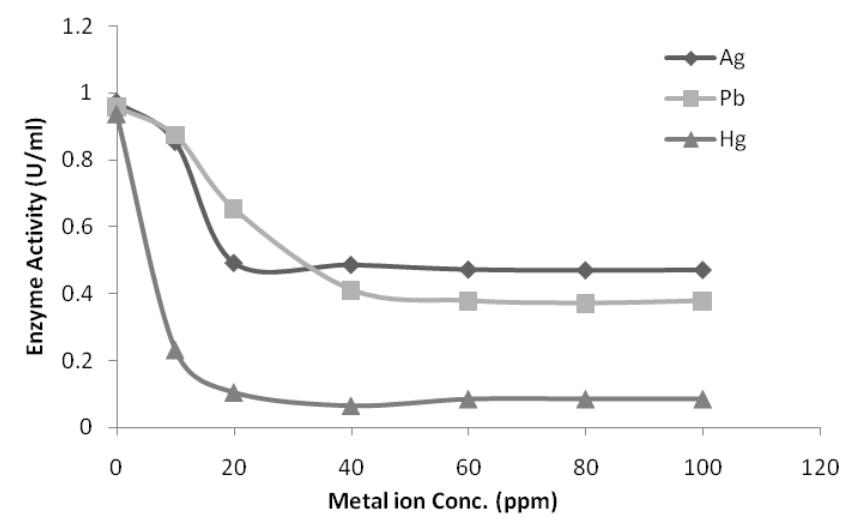

Fig. (4). Metal ion inhibiton of endoglucanase activity.

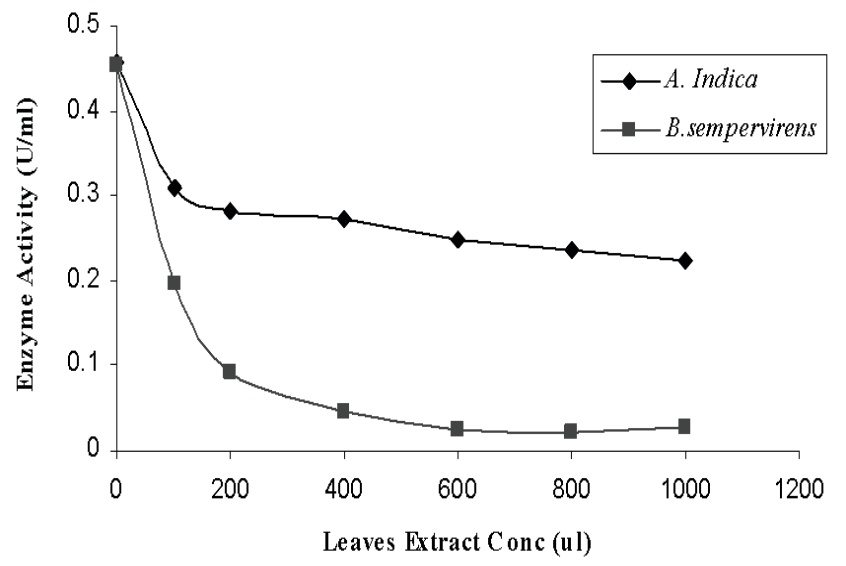

Fig. (5). Effects of plant leave extracts on endoglucanase activity.

Acetone soluble fraction was further treated with butanol, chloroform, benzene, hexane and petroleum ether respectively. Each fraction was checked for the inhibition of cellulolytic activity and presented in Fig. (6).

\section{RESULTS AND DISCUSSION}

\section{Screening of Cellulolytic Activity}

After staining and destaining, cellulase activity was observed using the substrate agar plate assay. It was observed that cellulase activity was present in the crude protein extract by observing the cleared zone formation around the sample well against a red-stained background on agar plates. At different concentration of the substrate, using CMC 2-3.0\% in assay mixture, keeping the enzyme amount constant, the cellulase activity increased with increase in concentration upto $2.25 \%$. The increase in activity was observed very rapid upto concentration of $1.5 \%$ which further attained equilibrium at $2.25 \%$ (Fig. (1). After increasing the concentration $(>2.25 \%)$ of substrate, no increase in activity was seen.

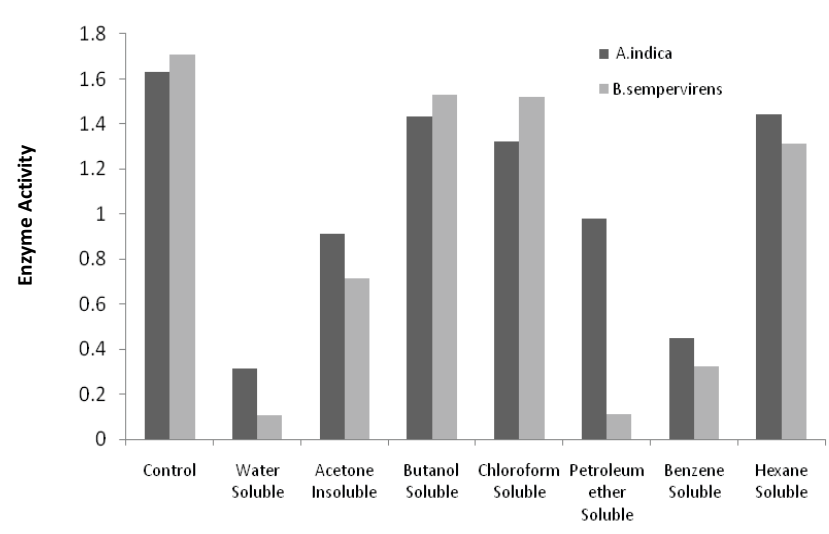

Fig. (6). A. indica and B. sempervirens leaf fractions treated with solvents of decreasing polarity.

\section{pH and Temperature Profile}

$\mathrm{pH}$ optima for maximum endoglucanase activity was calculated and found to be 5.4 as shown in Fig. (2). It was observed that at $\mathrm{pH} \mathrm{4.4,} \mathrm{the} \mathrm{activity} \mathrm{was} \mathrm{little} \mathrm{bit} \mathrm{lower} \mathrm{than}$ at 5.4. A negligible enzyme activity was observed beyond this $\mathrm{pH}$. Moreover, no activity was observed at $\mathrm{pH}$ values below 4.4 and above 8.5 .

In order to convert substrate into product, temperature play a vital role as enzyme has to collide and bind with the substrate at the active cites. The experiment was run at different temperature and found optimum CMCase activity at $50^{\circ} \mathrm{C}$. A gradual increase was observed in the activity with the increase in temperature upto $50^{\circ} \mathrm{C}$ however, an abrupt decline in enzyme activity was noticed above $50^{\circ} \mathrm{C}$ (Fig. 3). Although some enzyme activity was observed at temperature $40^{\circ} \mathrm{C}$ but that was almost half than the activity showed at $50^{\circ} \mathrm{C}$. From the results, it was concluded that $50^{\circ} \mathrm{C}$ is the best temperature to increase the collision of enzyme and substrate at unit time. Further increase in temperature has sharply decline the activity which may be attributed to decomposition of enzyme [26].

\section{Effect of Heavy Metal Ions}

For determination of enzymatic activity at different dozes of heavy metals like $\mathrm{Ag}^{+}, \mathrm{Pb}^{++}$and $\mathrm{Hg}^{++}$various concentrations of silver nitrate, lead acetate and mercuric chloride were used. The results are shown in Fig. (4). A gradual decrease in enzyme activity was observed with the increase of silver concentration but remained constant after $20 \mathrm{ppm}$ of $\mathrm{Ag}^{+}$concentrations. The results indicated that although $\mathrm{Ag}^{+}$ions reduced the most of activity of enzyme, but still there some activity was observed even at highest concentration of $\mathrm{AgNO}_{3}$. Contrary to $\mathrm{Ag}^{+}$, a decline in reaction rate was observed when lead acetate was added in higher concentration in case of CMCase activity and almost no activity was seen at $100 \mathrm{ppm}$. The CMCase activity was strongly inhibited by mercury and at $20 \mathrm{ppm}$ mercuric chloride totally inhibited the enzyme activity (Fig. 4). The data suggest that all three of the investigated heavy metals inhibited the enzyme activity in acetate buffer. However, the inhibition is not seen in case of $\mathrm{Ag}^{+}$which is consistent with the previous investigation [27]. From the results it is also 
hypothesized that these metals are non-essential metalloids and are capable of interference with normal biological functioning which results in the inhibition of enzymatic activity.

\section{Inhibition with Leaf Extracts of $A$. indica and $B$. sempervirens}

Results revealed that water soluble leaf extracts of both $A$. indica and $B$. sempervirens strongly inhibited CMCase activity which declined to almost zero at high concentrations (Fig. 5). B. sempervirens showed steep inhibition with increase in concentration and reached to zero at $800 \mu \mathrm{l}$ concentration whereas in the case of $A$. indica, the inhibition activity was observed gradually and reached to zero at $1000 \mu \mathrm{l}$. Moreover, acetone insoluble fractions from $B$. sempervirens containing the proteins and peptide also showed the diminishing of CMCase activity (Fig. 6). Different leaf extract fractions, from both plants $A$. indica and $B$. sempervirens, soluble in solvents with decreasing polarity showed the decrease in enzyme activity whereas, fraction soluble in benzene and petroleum ether indicated the maximum inhibition (Fig. 6). Petroleum ether fraction of $B$. sempervirens has the highest inhibition capabitiy and is compatible to that $A$. indica aqueous fraction. From the trend, it is concluded that $B$. sempervirens leaf extract can be used as enzyme inhibition for control in $P$. citri attack on citrus varieties.

\section{CONCLUSION}

From the trend, it is concluded that B. sempervirens leaf extract can be used as enzyme inhibition for control in attack on citrus varieties. Plant extracts of $A$. indica and $B$. sempervirens, have potential to inhibit endoglucanase activity leading to malnourish and death of pest i.e., $P$. citri which can be used as potent botanical pesticides. Isolation and characterization of active peptides may lead to development of some potent biological pesticide.

\section{REFERENCES}

[1] Beguin P. Molecular biology of cellulose degradation. Annu Rev Microbiol 1990; 44: 219-48.

[2] Goyal A, Ghosh B, Eveleigh D. Characteristics of fungal cellulases. Bioresource Technol 1991; 36: 37-50.

[3] Kikuchi T, Jones JT, Aikawa T, Kosaka H, Ogura N. A family of glycosyl hydrolase family 45 cellulases from the pine wood nematode Bursaphelenchus xylophilus. Mol Plant Microbe Interact 2004; 572: 201-5.

[4] Smant G, Stokkermans JP, Yan Y, et al. Endogenous cellulases in animals: isolation of beta-1, 4-endoglucanase genes from two species of plant-parasitic cyst nematodes. Proc Natl Acad Sci USA 1998; 95: 4906-11.

[5] Sugimura M, Watanabe H, Lo N, Saito H. Purification, characterization, cDNA cloning and nucleotide sequencing of a cellulase from the yellow-spotted longicorn beetle, Psacothea hilaris. Eur J Biochem 2003; 270: 3455-60.
[6] Xue XM, Anderson AJ, Richardson NA, Anderson AJ, Xue GP, Mather PB. Characterisation of cellulase activity in the digestive system of the redclaw crayfish (Cherax quadricarinatus). Aquaculture 1999; 180: 373-86.

[7] Watanabe H, Tokuda G. Animal cellulases. Cell Mol Life Sci 2001; 58: 1167-78.

[8] Li L, Frohlich J, Pfeiffer P, Konig H. Termite gut symbiotic archaezoa are becoming living metabolic fossils. Eukaryot Cell 2003; 2: 1091-8.

[9] Breznak JA, Brune A. Role of microorganisms in the digestion of lignocellulose by termites. Annu Rev Entomol 1994; 39: 453-87.

[10] Varma A, Kolli BK, Paul J, Saxena S, König H. Lignocellulose degradation by microorganisms from termite hills and termite guts: a survey on the present state of art. FEMS Microbiol Rev 1994; 15: 9-28

[11] Watanabe T, Kasahara N, Aida K, Tanaka H. Three N-terminal domains of beta-1,3-glucanase A1 are involved in binding to insoluble beta-1,3-glucan. J Bacteriol 1992; 174: 186-90.

[12] Bhat MK. Research review paper: cellulases and related enzymes in biotechnology. Biotechnol Adv 2000; 18: 355-83.

[13] Krishna K, Weesner FM. Biology of Termites. New York: Academic Press 1969; vol. 1: pp. 525-57.

[14] Culei J. Methodology for analysis of vegetable drugs: practical manual on the industrial utilization of medicinal and aromatic plants. Bucharest Office of the Joint UNIDO: Romania 1989; vol. 2-3: pp. 66-7.

[15] Peralta RM, Terenzzi HF, Jorge JA. $\beta-D$ glucosidase activities of Humicola grisea. Biochim Biophys Acta 1990; 1033: 243-9.

[16] Dunaevskii YE, Gladysheva IP, Pavlukova EB, et al. The anionic protease inhibitor BBWI-1 from buckwheat seeds: kinetic properties and possible biological role. Physiologia Plantarum 1997; 100: 483-8.

[17] Ishimoto M, Chrispeels MJ. Protective mechanism of the Mexican bean weevil against high levels of a-amylase inhibitor in the common bean. Plant Physiol 1996; 111: 393-401.

[18] Gatehouse AMR, Down R, Powell KS, et al. Transgenic potato plants with enhanced resistance to the peach potato aphid Myzus persicae. Entomol Exp Appl 1996; 79: 295-307.

[19] Fuchs A. On the gelation of pectin by plant extracts and its inhibition. Acta Bot Neerl 1965; 14: 315-22.

[20] Smart WWG, Bell TA, Stanley NW, Cope WA. Inhibition of rumen cellulase by an extract from serieea forage. J Dairy Sci 1961; 44: 1945-6.

[21] Byrde RJW, Fielding AH, Williams AH. The role of oxldlzed polyphenols in the varietal resistance of apples to brown rot. In Pridham JB, Ed. Phenolics in Plants in Health and Disease. Oxford: Pergamon Press 1960; p. 131.

[22] Tariq MI, Afzal S, Hussain I, Sultana N. Pesticides exposure in Pakistan: a review. Environ Int 2007; 33:1107-22.

[23] Isman MB. Botanical insecticides, deterrents, and repellents in modern agriculture and an increasingly regulated world. Annu Rev Entomol 2006; 51: 45-66.

[24] Teather RM, Wood, PJ. Use of congo red polysaccharide interactions in enumeration and characterization of cellulolytic bacteria from the bovine rumen. Appl Environ Microbiol 1982; 43 . 777-80.

[25] Nelson N. A photometric adaptation of the Somogyi method for the determination of glucose. J Biol Chem 1944; 153: 375-80.

[26] Peterson ME, Daniel RM, Danson MJ, Eisenthal R. The dependence of enzyme activity on temperature: determination and validation of parameters. Biochem J 2007; 402: 331-7.

[27] Kadiiska M, Stoytchev T, Serbinova E. On the mechanism of the enzyme-inducing action of some heavy metal salts. Arch Toxicol $1985 ; 56: 167-9$ 